\title{
MULTITUD Y TRADICIÓN EN \\ EL ENTIERRO DE CORTIJO \\ DE EDGARDO RODRÍGUEZ JULIÁ
}

\author{
POR \\ JUAN DUCHESNE WINTER \\ Universidad de Puerto Rico
}

La obra es la mascarilla de muerte de su concepcion. Walter Benjamin

El ensayo narrativo de Edgardo Rodríguez Juliá, que ofrece su testimonio del entierro multitudinario de Rafael Cortijo, inevitablemente invoca, al unir un tema fúnebre y una reflexión sobre el destino de la cultura de Puerto Rico, la conocida constelación de metáforas de enfermedad y muerte manejadas por quienes en el pasado han hecho similares reflexiones. Es el tipo de metáfora que de alguna forma emerge en frases como Réquiem por una cultura, título de un

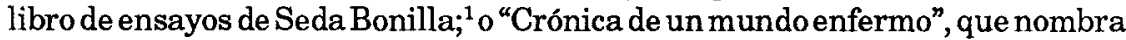
el ciclo de novelas de Zeno Gandía, junto a los epitetos que en una de esas novelas (La charca) designan a un "pueblo moribundo"; ${ }^{2}$ más la impactante sentencia de Salas y Quiroga registrada por Alejandro Tapia: "Puerto Rico es el cadáver de una sociedad que no ha nacido" ${ }^{3}$ Dichas metáforas comparten el campo semántico de lo mortuorio, sirviendo como figuras retóricas que condensan cierto pesimismo o aprehensión confusa ${ }^{4}$ del problemático desarrollo de la cultura puertorriqueña; pero ello no implica, por supuesto, que manifiesten una misma perspectiva de análisis. Y la obra de Edgardo Rodríguez Juliá resalta porque, además de no compartir las perspectivas de los escritores mencionados, traspasa el empleo retórico de metáforas mortuorias, y visualiza, no el hecho cultural como manifestación de la muerte, sino la muerte como acontecimiento cultural. Palpa, a raíz del deceso de uno de nuestros creadores culturales, lo que llama "el desgarramiento múltiple del país, las fisuras que ya pronto dolerán". ${ }^{5}$ Rodríguez

\footnotetext{
${ }^{1}$ Eduardo Seda Bonilla, Réquiem por una cultura. Río Piedras: Edil, 1970.

2 Jose Luis González, El país de cuatro pisos y otros ensayos (Río Piedras: Huracán, 1980) $70-76$.

s José Luis González,Literatura y sociedad en Puerto Rico (México: FCE, 1976) 89-90.

${ }^{4}$ Sobre la confusion que adjudican a nuestro pueblo algunos ensayistas, proyectando en realidad la suya propia, ver el caso de Pedreira, en Juan Flores, Insularismo e ideologta burguesa (nueva lectura de A. S. Pedreira), (Río Piedras: Huracán, 1979) 64.

${ }^{5}$ Edgardo Rodriguez Juliá, El entierro de Cortijo (Río Piedras: Huracán, 1983) 93.
} 
Juliá, aparte de las dos novelas que se le conocen, ${ }^{6}$ es ya autor, con ésta, de dos crónicas de entierro. La primera, Las tribulaciones de Jonás (1981), explora sobre todo el significado que cobra en la imaginación de nuestro pueblo la figura de Luis Muñoz Marín, máximo propulsor del populismo colonial de mediados de siglo. La segunda crónica, Elentierro de Cortijo, sobrepasa la figura desaparecida y profundiza la interrogación sobre la realidad cultural de Puerto Rico iniciada en la anterior. La descripción de la procesión fúnebre del gran compositor propone una lectura de la ruta cultural del Puerto Rico contemporáneo. Al testimoniar el progreso del cortejo, el escritor intenta construir una alegoría cuyas conexiones verticales y horizontales se desplazan, donde los signos consolidados en un punto se desvanecen en el otro frente a la temeridad semiótica de los innumerables personajes que integran el acontecimiento.

Conviene declarar, a través de una versión reporteril, los sucesos del rito fúnebre realizado por la multitud, que el seis de octubre de 1982 acompañó el cuerpo de Rafael Cortijo Verdejo al Cementerio de Villa Palmeras en la zona capital de Puerto Rico. Es una versión empírica de un reportero extranjero, que neutraliza la semiosis conflictiva que será indagada por el discurso simbólico de nuestro narrador:

Aproximadamente 10.000 dolientes salieron cantando y bailando del caserío público Luis Lloréns Torres y barrios adyacentes, ayer Miércoles, para acompañar la festiva procesión fúnebre del músico Rafael Cortijo hacia el cementerio de Villa Palmeras .... Tres limosinas cargadas de flores encabezaron la marcha a lo largo de las calles Providencia y Puerto Rico en Santurce. Los cantantes Ismael Rivera y Cheo Feliciano, los músicos Mickey Cora, Miguelo' y Peter Conde, junto al pelotero Orlando Cepeda, cargaron el féretro. Tras ellos, en un camión, iban los Pleneros de la Calle Loiza tocando las canciones de Cortijo.... Los niños salían de los salones de clase y se aglomeraban contra las cercas para alcanzar a ver el féretro y a los músicos. Varios en la multitud tomaban parejas y bailaban al ritmo de la música; cada número extraía vítores de reconocimiento al comenzar.... Sólo cuando la bandera puertorriqueña fue desplegada sobre el féretro y algunos comenzaron a cantar la Borinqueña, la muchedumbre se aquietó y entonó el himno nacional. Pero poco después "El bombón de Elena" sonaba en los altoparlantes ante un entusiasta aplauso. Era el primer éxito musical de Cortijo, el número introductorio de cada actuacion suya. La gente comenzó a bailar bomba y plena dentro y fuera del cementerio, lo cual se prolongó hasta mucho después del fin del acto.

Independientemente de la visión personal del reportero, y a pesar de la claridad descriptiva lograda, la prosa periodística impide puntualizar la resistencia sociocultural planteada por este funeral extraordinariamente

${ }^{6}$ La renuncia del héroe Baltasar y La noche oscura del Niño Avilés.

${ }^{7}$ Karen Lowe, "10,000 Give Cortijo a Rousing Farewell", The San Juan Star, 7 de octubre de 1982. La traducción es nuestra. 
sincrético, divergente de las pautas rituales que regulan este tipo de acontecimiento en el país. Siglos después de los repetidos concilios, sermones y decretos con que las civilizaciones europeas prohibieron bailar en entierros y camposantos, cobra impulso masivo dicha práctica, aquí sustentada en el arraigo de nuestra producción musical afroantillana. Una tradición oprimida, que sólo mantiene una presencia sinuosa y discontinua en nuestro país (pero que, por otra parte, no se ha limitado necesariamente al baquiné de infantes) ${ }^{8}$ resurge en una acción de masas, sin que sea absorbida por el discurso de los medios informativos como otra cosa que una novedad folklórica: cosa de "niños grandes". ${ }^{9}$ Toca a la crónica de Rodríguez Juliá desprender del acontecimiento las lascas que desmienten su neutralidad folklórica, y descubrir el drama agónico que lo constituye, en el contexto de la crisis colonial puertorriqueña.

Edgardo Rodríguez Juliá es nuestro cronista de la multitud. Desarrolla como pocos el tenor alegórico que en la literatura ha cobrado la inmersión del intelectual en la multitud. Históricamente, a raíz de esa inmersión, el escritor siempre ha propuesto un caso enigmático, suscitado por su papel de peregrino ante quien desfila la confusión social misma, en la cual debe leer (o escribir) la galería de tipos, figuras, virtudes, vicios, fuerzas e intereses que deletrean la SOCIEDAD CIVIL. No importa que ésta proyecte una utopía, distopía o sociedad "realmente existente". Allí, frente al fenómeno de la multitud, el escritor halla la oportunidad irrenunciable de oficiar la voz memorial y profética de su escritura. Congrega entonces los ingredientes alegóricos con que cifra su enigma de lo social: el testigo (el escritor), el agente demoníaco que fija o desplaza las máscaras del sentido (la multitud) y las máscaras mismas (los rostros del "cosmos"). ${ }^{10}$ Tal vez no haya nadie que ilumine como Walter Benjamin el avatar de la multitud en agente demoníaco de la visión poética moderna. Sus Iluminaciones hablan de la multitud convocada a ningún sitio, en mil itinerarios, por la circulación de la mercancía en la sociedad capitalista, fenómeno que hace a Baudelaire enunciar, "El placer de estar en las multitudes es una expresión misteriosa del goce por la multiplicación del número";

- Falta por hacer un estudio científico del desarrollo de esta forma cultural en la actualidad. Referimos el comentario a nuestra observación personal: Manuel Álvarez Nazario, El elemento afronegroide en el español de Puerto Rico (San Juan: I.C.P., 1961) 276-79, sobre el baquiné; Paulo de Carvalho Neto, La obra afrouruguaya de Idelfonso Pereda Valdéz (Montevideo: C.D.F.V., 1955) 129-21, sobre los rituales fúnebres de la nación Congo en Montevideo; Aquiles Escalante, El negro en Colombia (Bogotá: Universidad Nacional de Colombia, 1964) 161-69, sobre el ritual lambalú del Palenque de San Basilio en Colombia. Éstas y otras fuentes más especializadas demuestran cómo la tradición pasada de los ritos afronegroides de la muerte en Puerto Rico exhibe ciertos paralelismos con respecto a América Latina y al Caribe.

${ }^{9}$ Prensa capitalina del 7 de octubre, 1982, en especial El Nuevo Dia.

10 Descartamos aquí la oposición modo simbólico/modo alegorico que va de Goethe a Lukács. En Lukács Estética. Tomo 4 (Barcelona: Grijalbo, 1967) 423 y ss.

${ }^{11}$ Walter Benjamin, Iluminaciones II (Madrid: Taurus, 1972) 74. 
intolerante, un dicho de Grey: "quien se abruma en el seno de la multitud es un imbécil, un imbécil y yo lo desprecio" (Iluminaciones, 51). Frase entendible en el escritor, intrigado al sentir lo que Benjamin llama el "escalofío de la economía mercantil” (Iluminaciones II, 74-75), el cual se agudiza en cuanto la posición social del escritor hace cada vez más evidente la naturaleza mercantil de su fuerza de trabajo. ¿Qué congregación selectísima - parece preguntar Benjamin - puebla la ciudad, si no es la de la mercancía, cuyo régimen arrastra la avalancha de seres que en ella mutan y venden su fuerza de trabajo, a la vez que reifican, compran y mendigan sus necesidades? No es un misterio para nadie que la ciudad reúne las mercancías, amontona los cuerpos y aísla los seres humanos, vista desde el flanco de su negatividad histórica. Más o menos así la ve, "flâneur" o callejero revolucionario, Federico Engels, citado también por Benjamin. Engels pondera en su descripción de una multitud callejera el espectáculo de esa centralización colosal, ese amontonamiento de tres millones y medio de hombres en un solo punto [que] ha centuplicadola fuerza de esos tres millones y medio, -pero advierte cómo-cientos de fuerzas que dormitaban en ellos han permanecido inactivas, han sido reprimidas", dada "la indiferencia brutal, el aislamiento insensible de cada uno de ellos en sus intereses privados" (Iluminaciones 73-74). El siguiente comentario de Benjamin aproxima aún más nuestro trazo al tipo de manifestación multitudinaria explorada por el texto de Rodríguez Juliá. Analiza así la aglomeración callejera espontánea mistificada primero por un Víctor Hugo y anulada por el totalitarismo nazi en la época en que escribía:

\begin{abstract}
Una calle, un incendio, un accidente de tráfico reúnen a gentes libres de determinación de clase. Se presentan como aglomeraciones concretas; pero socialmente siguen siendo abstractas, esto es, que permanecen aisladas en sus intereses privados. Su modelo son los clientes que, cada uno en su interés privado, se reúnen en el mercado en torno a la 'cosa común'. Muchas veces esas aglomeraciones tienen s6́lo una existencia estadística. Queda en ellas oculto lo que constituye su monstruosidad, a saber: la masificación de personas privadas por medio del azar de sus intereses privados. Si esas aglomeraciones llegan a saltar a la vista (y de ello se cuidan los Estados totalitarios en cuanto hacen obligatoria y permanente para todo propósito la masificación de sus clientes), sale claramente a la luz su carácter ambiguo (Ilu minaciones $I I, 79$ )
\end{abstract}

Por su parte, el rito fúnebre intentaría una aglomeración social motivada, de tendencia contraria al encuentro azaroso arriba descrito. Es una aglomeración posterior al accidente de la muerte que instala el interés privado dentro de la crisis colectiva desatada por la presencia del muerto en tanto colapso del cuerpo humano como significante vital. ${ }^{12}$ Ese "dolor asumido como obligación

\footnotetext{
12 Jean-Thiery Maertens, Le Jeu du mort. París: Aubier Montaigne, 1979. Referimos las distinciones conceptuales aquí empleadas a esta gramática de la muerte.
} 
comunitaria" descrito por Rodríguez Juliá es una actividad colectiva en que la energía emocional de los deudos convoca los miedos, angustias e histerias individuales de la comunidad hacia la conversión del duelo en trabajo significante, en memoriay promesa de orígenes y destinos comunes aunados contra la solitaria descomposición del cuerpo. Pero la aprehensión de la tendencia solidaria de un rito concreto, comoel que reúne espontáneamente una muchedumbre en Puerto Rico hoy, sería estéril si no se tomara en cuenta la particular forma histórica en que está transido de la alienación que los escritos de Benjamin advierten y que el propio Rodríguez Juliá palpa en su testimonio. Su crónica del entierro de Cortijo explora justo la lucha entre rito y masificación, tradición y olvido en el caos del acontecimiento público isleño. (Entierro 72).

Cuando penetra en la multitud del entierro, el narrador ya no es el flâneur de la modernidad europea sino un novelero "inteligente" (según se autodenomina con ironía). Participa en la "cosa común" que une a la mayoría del cortejo en mezcla de duelo y afición novelera. Pero no deja de introducirse en el relato como intérprete de la alegoría, cuyas reflexiones testimoniales proveen la guía anagógica del enigma. Está adentro y está afuera, respondiendo al particular cronotopo ${ }^{13}$ de su ensayo narrativo: la inmersión del intelectual en la multitud como testigo inmediato de sus rumbos y errares. Llega al barrio semi-proletario de la ciudad donde se origina el entierro convencido de que debe adoptar "nuevas categorías para describir esto" (Entierro 85), en función de una perspectiva que irá definiendo a lo largo del relato como visión desde el interior y a la vez distanciada con respecto al acontecimiento, y por tanto, irremediablemente conflictiva. "Pretendo ver el entierro desde todos los ángulos posibles", declara en un punto, y en otro percibe la equivocidad de su intención:

[q]uise esperar la llegada de la comitiva, me interesaba la toma frontal, la panorámica que me entregaría una perspectiva emblemática del entierro, algo así como una foto de caseta o una ficha de preso. Ahora quiero un golpe de vista que sea capaz de resumir toda esta complejidad. Pero ocurre que la multitud resulta incapaz de posar. Una multitud jamás asume pose, a menos que se trate de los "rallies" nazis de Nuremberg.... No, es imposible, tendré que volver a los rostros, a los individuos, para que esto signifique algo (Entierro 77).

Debe permanecer en el inenarrable tiempo y lugar de la multitud, captando y descartando emblemas, percibiendo los "golpes de vista" que cifran la alegoría, perorenunciando al encuadre fotográfico que quebraría la escena con un "shock" de fijeza. Su recuento oscila entre el resumen diegético, la descripción de escenas y numerosos predicados analíticos (que le confieren un tono de ensayo), alcanzando a establecer cierto lazo ficticio entre el tiempo de la historia y el

${ }^{13}$ M. M. Bakhtin, The Dialogical Imagination (Austin: University of Texas Press, 1981) 250. El cronotopo es un motivo espacial y temporal que centraliza la representación narrativa. El vocablo fue tomado por Bakhtin de las ciencias físicas. 
tiempo de la narración. Se produce el efecto ilusorio de que quien narra discurre sobre lo que describe en el momento mismo en que participa en el entierro. El monólogo casi ensayístico del narrador aparece como flujo de conciencia que acompaña la percepción de los hechos descritos. Resulta un habla interior, simultánea a los estados de mundo exteriores, que desafía la brecha entre el tiempo de la historia, y el tiempo de la narración y pretende sustituir toda tecnología de registro directo:

Morenos, morenos por todos lados y sólo una Mont Blanc para escribir .... No, el oficio de cronista dieciochesco me lo prohibe: ni siquiera una libreta, ni una grabadora, tampoco una cámara Minox. Prefiero escribir la crónica pasándola sólo por el ojo y el oído, soy tercamente subdesarrollado, basta con escribir al otro día, cuando la memoria aún conserva frescos los detalles. El filtro del cronista es la memoria, la personal y la colectiva, también los prejuicios, ¿por qué no? ( $E l$ entierro, 17).

Este pasaje yuxtapone el tiempo en que se escribe y el tiempo en que se presencia el acontecimiento. La primera frase contiene una percepción radicada en el tiempo del acontecimiento, pero la segunda traslada el suspenso al acto de la escritura. La oposición irónica de "morenos" y "Mont Blanc" refuerzael contraste temporal con connotaciones raciales. Quedan entrecruzadas, la perspectiva del testigo que presencia los hechos y la perspectiva del escritor que, frente a su máquina de escribir, batalla contra la radical ausencia del acontecimiento. Esta última se distancia aún más dentro de la connotada pertenencia a la esfera cultural "blanca" o blanqueada. Pero el suspenso aúna los instantes de la calle y el escritorio: "ya se perfila que esta crónica será el encuentro de muchos cruces históricos" (El entierro 12-13) -afirma el narrador, aludiendo tanto al orden de hechos por desarrollarse, desde su punto de vista de personaje de la historia, como al texto por revelarse, desde su punto de vista de autor que lo presenta. Confunde acontecimiento, escritura y hasta lectura, con anticipaciones ambiguas; descarta hábilmente la visión posterior del narrador histórico; salva en fín la distancia "entre el momento vivido y la crónica escrita", trasponiéndola a la inmediatez de la lectura en la forma de suspenso.

La entrada al sector de Lloréns Torres se anuncia como paródico descenso de un "blanquito" conspicuo (Entierro 15) al "averno" semiproletario, "terrible extensión mítica", donde "los cuentos son terribles" (Entierro 12), expresiones irónicas que designan el supuesto barrio maldito de la urbe colonial, poblado de borrosas estirpes. Allí el narrador se precipita en la múltiple confusión de entierroespectáculo de la que en alguna medida participan todos los concurrentes. Las diferentes "tomas" (para proseguir con las analogías fotográficas del texto) presentan, junto al sincretismo creador de algunos gestos, el puro caos de la masificación urbana: "un ir y venir de actitudes encontradas, casi extrañas a eso que se llama la ocasión luctuosa" (Entierro 50). La muchedumbre encarna una "bestia novelera" (Entierro 85), un "molote de cuerpos" (Entierro 84) que 
atenta contra el ejercicio de interpretación del intelectual. A veces la amenaza de completa confusión lo abruma: "la ansiedad me asalta y temo un desmayo jactancioso de blanquito metido en baile de gallina; todas las percepciones se confunden, se trata del atronador sincretismo de estas tierras, de la total ausencia de tradición y propiedad" (Entierro 87). Pero al parecer el autor se pregunta si dicha confusión no deriva de su postura abstrayente, si no está olvidando alguna profunda complicidad, como la sugerida por el espectáculo de "cuatro hembras bochincheras" con pantalones a reventar:

jcoño!, esto no es un país, y ¿por qué entonces tú, contaminado por el general desarreglo, no puedes olvidar que esos trapiches de sensual zafra también deben tener el ancestral aroma marino justo en su punto cuando el inclemente sol de Borinquen Bella perfectamente golpea a mediodía las techumbres de zinc de la antillana Villa Palmeras? (Entierro 87)

La multitud no presenta una sola faz caótica: recordemos que es el demonio de esta alegoría, el "daiomai", genio de las buenas o malas inspiraciones, agente revelador de destinos colectivos. ${ }^{14}$ Estamos lejos de las inermes turbas de pálidos de Zeno Gandía. Gracias quizás a su propia contaminación con el "desarreglo" multitudinario, el narrador va descifrando los cosmos de una red de elementos sociales, culturales e históricos que determinan su imagen del acontecimiento, toda vez que privilegia la visión no panorámica que capta las individualidades del conjunto según los cuadros de Brueghel a que alude en el texto.(Entierro 52) Ensayamos aquí la acepción ya perdida del "cosmos": el detalle, ornamento o insignia que denota la posición del portador en un universo de interrelaciones mutuas. ${ }^{15} \mathrm{El}$ primer y determinante cosmos en las descripciones de Rodríguez Juliá es la mercancía, transmutada casi siempre en vestuario, es decir, máscara del cuerpo que lo reviste de su aura fetichista. ${ }^{16}$ "La pizpireta mulatita que destacala sabrosura de su culito contento con esos mahones cuya costura trasera Chardón abre los gajos de la nies" (Entierro 20). ${ }^{17}$ El gesto destacante de lainsignia comercial Chardón, invoca el poder adquisitivo mediante el que un trasero femenino alcanza la visibilidad y disponibilidad pública de la mercancía que lo reviste. La prenda exhibida es signo cósmico, y por tanto alegórico de una modalidad parcial del cuerpo de la chica equiparable al radio Panasonic que sostiene en la mano en tanto signo de sus oídos (mencionado más abajo en la descripción). Ambos objetos le confieren una identidad consumidora

\footnotetext{
${ }^{14}$ Angus Fletcher, Allegory (Ithaca: Cornell University Press, 1964), 42-44 y ss. A esta obra referimos la concepción de lo alegorico que subtiende nuestro análisis.

${ }^{16}$ A. Fletcher, Allegory, 112 y ss.

16 "Experimentar el aura de un fenómeno significa dotarlo de la capacidad de alzar la vista", dice W. Benjamin (Iluminaciones II) 163.

${ }^{17}$ Rodriguez Juliá, El entierro, 20. Subrayados del autor. Nies, de bastante uso en el Caribe, denota una región venérea ambigua: " $n i$ es una parte, ni es la otra".
} 
que fracciona su cuerpo en esferas de valor de cambio, identidad abstracta que prescinde de su identidad unitaria y concreta de persona. La circulación sígnica de la multitud sigue los hilos centrífugos de una moira moderna: la circulación de la mercancía. Brillan por su presencia en el relato los cutis Camay y Palmolive, los pies calzados de Florsheim y Adidas; justo en la descripción de un entierro, como si el cese de la actividad simbólica concreta del cuerpo humano signado por el cadáver pudiera también conjurarse a través de las máscaras siempre circulantes de la mercancía. ¿Pero no es esa otra muerte? ¿Otra mutilación a través de la sinécdoque fetichista del vestuario?

Notemos, sin embargo, que la descripción erótica de la "mulatita" se sitúa en el mismo recinto donde cumple su fin el velorio, en este caso el espacio más melancólico y ortodoxo del ritual descrito. La música, aunque tolerada, se supone permanezca afuera, pero lachica ha entrado con su radio encendidoy pantalones super apretados, ${ }^{18}$ desafiando el saber dominante de la muerte, proponiendo, con su desarticulación de los ideogemas del duelo civil, un trabajo de duelo alterno, aunque incompleto o inconsistente. El aparato y el vestuario ofrecen su otra cara, en tanto medios expansivos de la actividad erogenizante del cuerpo humano, sugiriendo nuevos valores de uso en el sistema de signos sociales. No empece su estado fragmentario, el gesto cobraría un valor de experiencia de resistencia. ${ }^{19}$ El texto, por su registro erótico del gesto, se hace cómplice del cuestionamiento de los ideologemas del duelo civil, los cuales impugna de manera más directa aún al rechazar (no sin cierta ambigüedad) lo que considera como "malos trucos dela materia" (Elentierro, 24): (el silencio formal, la exhibición del cadáver como si estuviera vivo, etc.): "Todo ello me parece una teología degenerada, una escatología decadente, espectacular y novelera" (El entierro, 24). Es el tipo de discurso que, según apunta Maertens, reduce todo trabajo de duelo a pose melancólica y "desvía el potencial de creatividad que la muerte podría despertar en cada uno, en el lugar mismo de la ausencia: cadaveriza a los sobrevivientes más que al cadáver. Ya no es el difunto quien se asemeja a los vivientes, sino los sobrevivientes quienes se asemejan al difunto, para beneplácito del poder en cuestión" ${ }^{20}$ Ante el silencio pasivo, espectacular, del rito ortodoxo (cuyas actuales expresiones en nuestra cultura, el narrador da en

\footnotetext{
${ }^{18}$ Investigadores británicos han propuesto ciertas manifestaciones de supuesto "descaro" sexual observado en la conducta de chicas de clase trabajadora, como formas culturales de oposicion al discurso autoritario y machista de sus centros de trabajo o escolares. Paul Willis y Philip Corrigan, "Order of Experience: The Differences of Working Class Cultural Forms". Social Text 7 (1983) 91.

${ }^{19}$ Willis y Corrigan "Order of Experience", 101. Willis y Corrigan catalogan este tipo de formas dentro de lo que constituiría una "experiencia de oposición". Preferimos adoptar el concepto cambiándolo a experiencia de resistencia, pues creemos que formas tan elementales aportarian a una experiencia de oposición sólo en un contexto de contienda política dentro del proceso de lucha de clases.

${ }^{20}$ Maertens, Le Jeu, 47.
} 
derivar del barroco) el pueblo recurre a la invención de señales vitales: "la vida como sonido queda burlada [por el 'truco' barroco]. Pero ya veremos cómo la comunidad le busca la vuelta a este asunto tan espinoso". ${ }^{21}$ La incursión irreverente de la chica es una de las formas de "buscar la vuelta". Ése y otros gestos proto-rituales anotados en las descripciones del texto niegan la clase de melancolía impuesta por instituciones ideológicas coloniales tales como la ortodoxia eclesiástica. A través de ellos ofrece la multitud las faces ocultas de una realidad sociohistórica cruzada de orígenes y destinos conflictivos.

Para Rodríguez Juliá el origen y destino siempre evasivos de la multitud que describe ya tienen poco o casi nada que ver con las esferas culturales de un patriciado hispánico compartido por figuras como Luis Lloréns Torres ("primero de esos cursilones abogados independentistas que luego concibieron, y conciben la poesía como el perfecto baja bloomers ${ }^{\prime 22}$ y los Martínez Nadal y Tous Sotos, o variaciones presentes como el ex-gobernador, Hernández Colón ("traductor colonial entre los amos y su pueblo") (Entierro 80), el Cardenal Aponte Martínez y hasta "esos marxistas de Peugeot, Volvo y Mercedes Benz que jamás conocieron, como yo conocí, la formación sentimental de la 65 de Infantería" (Entierro 75). Todos parecen representar distintos aspectos de un mundo al que el narrador mismo no niega pertenecer, cuya unidad mayor, pese a las contradictorias esferas que lo componen, radica en su distancia con respecto al mundo popular y mestizo representado en el relato por la multitud. La polaridad aquí visualizada corresponde a la fractura de la sociedad puertorriqueña en "dos formaciones nacionales" argüida en El país de cuatropisos de José Luis González, ${ }^{23}$ compuesta una de ellas del sector de clases trabajadoras que articula elementos de una cultura nacional-popular de característicos rasgos mestizos(afroantillanos e hispanoantillanos - en ese orden) y la otra, en su mayoría pero no exclusivamente, de sectores burgueses y medios que articulan la cultura nacional dominadora, de raigambre hispanoeuropea. Las formas tradicionales de esta última, según González, son las que en verdad padecen la erosión progresiva que se le atribuye a la totalidad de la cultura nacional, en razón del rol mediador asumido por sus sectores representativos frente al poder estadounidense. González aclara también que las articulaciones culturales adscribibles a ambos sectores traban lazos de coexistencia e influencia mutua que permean el conjunto social, no obstante la oposición continua dentro de la cual prevalece la segunda (llegando a representar de manera privilegiada a la Cultura Nacional puertorriqueña). El texto de Rodríguez Juliá se orienta más o menos dentro de un espectro de oposiciones similares, de acuerdoal que designa esferas contrarias para quienes representan "la antillanía proletaria" y el

\footnotetext{
${ }^{21}$ Rodríguez Juliá, El entierro, 24-25. Subrayados del autor.

${ }^{22}$ Rodriguez Juliá, El entierro, 13-14. Subrayados del autor. Bloomers: "Panties", bragas, calzones.

23 José Luis González, El pats.
} 
patriciado burgués. Pero la brecha tampoco es absoluta. Su versión extiende lo que veríamos, en este caso, como continuidades constructivas o destructivas que se entrecruzan en el terreno simbólico. La continuidad constructiva se produce, ante todo, en el propio trabajo discursivo de Rodríguez Juliá, el cual descarta los eufemismos y deferencias paternalistas que disimulan y a la vez refuerzan, en el orden literario, la relación desigual entre las citadas articulaciones culturales. A través de la ironía y la autoparodia (apreciables en los pasajes aquí citados) transparenta los prejuicios que informan su visión. Propone otra vía de continuidad constructiva el trazo aubiográfico de su temprana afición por la música afroantillana - carta de saber popular con que legitimiza su relato. Y resume su fe en la confluencia de aquellos elementos innovadores de ambas esferas culturales irreductibles a un único patrimonio étnico o de clase, la interpretación del episodio del "madamo" mulato que se apoya en el hombro del escritor para compartir el mismo lugar de observación del entierro:

\begin{abstract}
Quería treparse al lado mío y me usaba como asidero; aquella confianza me produjo un consuelo intimo, inefable, casi imposible de articular .... Quizá ya no soy tan distinto a él, quizá toda congregación es simplemente una u topia que ensaya su espacio futuro .... ¡Qué negro confianzu!! ¡Qué atrevimiento!, hubiese dicho uno de mis antepasados mallorquines ante esa mano que indistintamente buscaba asidero para treparse al muro de la muerte. Pero justamente ahi el gesto exclusivamente carnal perdía su ahistoricidad: Recuerda que ese gesto habria sido imposible en el 1910. Un negro madamo de aquel entonces simplemente no agarraba por la manga a un señorito con bigote de punta al ojo ... recuperado el signo histórico para el abrazo con mi otro abuelo, el madamo ahora quiso pasar por mi lado, y me agarró por los brazos para no caerse ...(El entierro, 94).
\end{abstract}

Aquí el narrador restituye la historicidad de un gesto opacado por el movimiento abstrayente de la multitud masificada, hallando a la vez un contactointertextual (nótese la alusión al conocido poema de Nicolás Guillén en el emblema del abrazo de los abuelos - ¿o no hay tal alusión?) con la tradición literaria del mestizaje.

Una descripción de igual agudeza sociohistórica desarrolla la continuidad destructiva entre las esferas de la "antillanía proletaria" y el patriciado burgués, a partir de la figura de un joven narcómano:

Pero una y otra vez me empujan a la acera; por aquí, frente a mí, pasa ese tecato de ojos a punto de estallar, la camisa por fuera le serviria para arroparse; seguramente la compró en Donato de la Loiza, que el camisón tiene la pinta de cansada mercancía de baratillo, y sus zapatos a dos tonos de crema y violeta trenzados en rejilla y con tacones tipo zapatacón; el sorprendente detalle rural en este joven teco de Lloréns es la cantidad de fango que tienen sus zapatos. Hay un cansancio en esos huesos que ya no tiene cura .... [más adelante] $\mathrm{Y}$ vuelvo a mi teco de zapatos aguacatones: "El desgaste! ¡The horror! ¡The horror!, como 
diría Conrad. No debe tener más de veinticinco años; su cuerpo ya es un organismo irrecuperable para la vitalidad .... Pero este tecato me enternece, en verdad os digo que como él hay muchos en el entierro, y algunos intentan imponer el orden .... .

$\mathrm{Al}$ leer la mercancía en la vestimenta, con un trazo metonímico que sigue los hilos de su circulación material y semántica, el texto reconstruye, con sorpresa, la máscara de la muerte en su advocación social, hegemónica y pública. Dentro del conjunto descriptivo hay un detalle dotado de aura cósmica que acentúa la perturbación de la figura entera: los zapatos de dos tonos. Un pasaje posterior indica el desplazamiento interno que éstos provocan en la memoria (recordemos el efecto de la magdalena proustiana). Son los zapatos que deben combinar con el traje dril de un antepasado del autor, don Benicio Fernández Juliá, legislador coalicionista que tras peligrosa sesión conjunta de amor y almuerzo, muere de un "patatús" en casa de su querida, la negra Chefa:

Entonces [Chefa] oy6 aquel larguísimo conmovedor suspiro postrero de don Benicio. Como un centellazo pasó por su cabeza la frase tantas veces temida: Le dio, le dio el patatús, le tiene que haber dado con ese .... Cuando Chefa llego, la bolsa de flatulencia todavía sonaba; pero aquel sonido ya correspondía más a la mecánica de los gases que a la vida del intestino grueso .... Saltó a gritarle, pero el viejo ya no contestaba; tenía la boca abierta, los ojos saltones y una mancha cárdena se traslucía en la papada y las mejillas (Entierro 65-66).

Introduce el episodio este juicio:

Corría el año 1937. Palés proclamaba, en su Tun tún de pasa y grifería, que la antillania proletaria de Villa Palmeras prevalecería sobre el recinto corso pequeño-burgués mallorquín del San Juan Antiguo y Miramar. Pero la realidad está hecha sólo en parte de visiones. Hay que acatar también la observación (Entierro 62).

El cosmos de un mundo ya fantasmagórico, insignia de jerarquía patricia, aparece calzando los pies de un hijo de aquella antillanía proletaria que en la visión del poeta debía prevalecer sobre el mundo de Miramar. Pero el calzador actual de los zapatos a dos tonos no es otro que una víctima de las relaciones sociales a través de las que se enfrentan los sectores trabajadores y burgueses isleños, bajo un modo de producción que sólo rearticula sus elementos materiales e ideológicos para profundizar las mismas contradicciones desquiciadoras. EI mundo señorial de un Fernández Juliá desapareció, pero engendra, en cierta manera, las elites del presente. Y el "teco" debe reaparecer en este entierro como necesario hijo de una Chefa. La antillanía proletaria sigue engendrando su prole, entre ellos, ángeles caídos como el "teco", en cuya figura reaparece el

\footnotetext{
${ }^{24}$ Rodríguez Juliá, El entierro, 39. Subrayados del autor. Tecato, teco: adicto a la heroina.
} 
detrito fantasmal de los victimarios, remembrando que la muerte no es asunto privado, sino escándalo social antagónico.

Sobre las epifanías interiores de Proust, Benjamin discierne que la memoria no sólo ha de ser involuntaria, no empece el prestigio que el novelista confiere a ese modo de recordar:

El concepto [de involuntariedad absoluta de Proust] lleva las huellas de la situación en la que se ha formado. Pertenece al inventario de la persona privada en su múltiple aislamiento. Cuando impera la experiencia en sentido estricto, ciertos contenidos del pasado individual coinciden en la memoria con otros del colectivo. Los cultos con su ceremonial, con sus fiestas, de las que en Proust apenas se habla nunca, llevaban a cabo renovadamente la amalgama de estos dos materiales de la memoria. ${ }^{25}$

Nuestro textointenta conjugar precisamente los episodios interioresy colectivos en una memoria única que rebase lo público y lo privado cumpliendo la amalgama convocada por el rito fúnebre (" $\mathrm{El}$ filtro del cronista es la memoria, la personal y la colectiva", declara un pasaje ya citado). Ése es el principal valor de los múltiples trazos autobiográficos aplicados al relato del entierro.

La memoria voluntaria se constituye al captar aquellos rasgos de la conducta de la multitud, rescatables como experiencia colectiva transformadora de los despojos y reivindicaciones del pasado. Se trata, quizás, de la búsqueda que define a este narrador como intérprete (y personaje) de la alegoría de la multitud. Las coincidencias pueden ser proféticas o irónicas: el cortejo atraviesa las calles Providencia y Puerto Rico sin que su curso aparente revelar providencialidad alguna para la cultura puertorriqueña. A veces el entierro se le aparece al narrador como "imitación de un cuadro plástico dedicado a la histeria" (Entierro 60). Pero desde el principio él decide a donde dirigirse dentro de ese cuadro. Tras sortear la inicial confusión de la entrada al barrio, se dice, "Apresuré el paso, Cortijo me espera como tabla salvadora" (Entierro 15), y va al Centro Comunal donde yace el cuerpo. Luego de comenzar la procesión se esfuerza por distinguir de alguna forma ciertas zonas significantes, para hallar en la cadena humana que rodea a los deudos, una "confusa frontera entre el dolor y la novelería" (Entierro 58), la cual ha decidido cruzar hacia la zona del dolor: "Quiero colocarme en el interior de la cadena, sería necesario para la crónica tener la cercanía de Maelo y la familia" (Entierro 56). Busca el centro de la procesión, el núcleo significante.

Allí oficia su enorme trabajo de duelo el popular sonero Ismael Rivera, o Maelo, mitad musical de Cortijo casi desde el inicio de sus creaciones. La fisonomía de Maelo aparece revestida del cosmos oracular:

La barba canosa le ha otorgado, por fin, una serenidad de sabio carabali. ... [más adelante] ... con ella podría pasar por sociologo de literatura caribeña a lo Bob Márquez (Entierro 38-39).

${ }^{25}$ Benjamin, Iluminaciones 128. 
El sonero posee una lengua secreta:

no entiendo nada de lo que dice; es como una jeringonza privada a una sola voz entre dos capitanes del mandinga soneo mayor, quizá alguna consigna cangá del Siglo XVIII, o un lenguaje íntimo y personal cuya clave sólo ellos conocían (Entierro 41).

Mientras el cardenal descarga su saber eclesiástico, Maelo prosigue con el "oscuro objeto de su diálogo" (Entierro 47), y oficia ritos que expresan algo más acá del culto estatuido:

Maelo no se conforma con la memoria. Quiere tocar la materia de su dolor; no pretende conseguir la tranquilidad que logro Cheo Feliciano cuando devolví el diminuto crucifijo a su sitio (Entierro 41).

El sonero abandona la pasividad de la melancolía y pacta una penitencia íntima y comunitaria cargada de gestos perturbadores, tales como caerle a dentelladas al cadáver, comunicarle frases indescifrables y quitarse la camisa después de portar el ataúd todo el camino, actuando "cual si fuera un héroe trágico sólo sostenido por el rumor del coro y la sinceridad equívoca del planto" (E 43). Según lo descrito, su treno mortuorio no memorializa: puro contenido de la memoria, se manifiesta como excedente incapitalizable por el saber dominante de la muerte. El sonero en duelo se hace memoria en sí, indomesticada, del espíritu plenero a la altura del cual ha actuado. Sus gestos alojan el centro del espacio plurisignificante desde el cual el texto articula su versión crítica del acontecimiento en tanto desenlace del episodio de la cultura nacional que Rodríguez Juliá llama "la segunda época de la plena". Necesario vacío de ese centro, alojado por el rito de Maelo, es el silencio de Cortijo.

La muerte ha liquidado el cuerpo viviente del artista, fuerza de trabajo productora de signos culturales que junto al producto de arte (la obra musical) cimenta al artista como personaje-signo. Tras la ruptura de la muerte (fin biográfico de quien protagoniza un episodio de nuestra cultura nacional) el significado de Cortijo amenaza dispersarse cual alma privada de su cuerpo. Su materialidad productiva concreta se desintegra. Surgen las preguntas sobre el comienzo y el fin, sobre lo que sigue o no sigue. La crisis de uno de los signos conmueve la red completa. Es necesario restituir el signo del hombre sobre otras bases que las de su continuidad material perdida. Se requiere el desenlace que sirva de eslabón a otros episodios. Entonces debe intervenir un rito que, a través del trabajo de duelo sobre el cadáver - al decir de Maertens_ “a falta de devolverle la vida, le confier[a] al menos significación en el resto de la cadena de objetos significantes". ${ }^{26}$ Desde el punto de vista de quien, como el narrador de nuestro texto, visualiza una cultura popular puertorriqueña, Ismael Rivera es máximo

${ }^{26}$ Maertens, Le Jeu 10. 
representante de ese trabajo de duelo en el entierro presenciado. $\mathrm{Al}$ margen del saber ortodoxo, sus gestos lo yerguen en deuteronomista (aquí protagoniza el silencio de Cortijo) de una de las tragedias del arte musical isleño. Pero el rito de Maelo y de quienes participan entendiéndolo o sin entenderlo (aún quienes confunden la irreverencia creativa ante la pose melancólica con la indiferencia alienada, en su errático abandono del decoro establecido), es un rito. La civilidad colonial proyecta el rito, desde el polo de la cultura dominadora; desde el que todo sucede, citando otra vez a Maertens:

como si el discurso organizador de significantes en la sociedad, localizara en la amenaza de un cadáver el cuerpo de delito capaz de ridiculizar su propia univocidad, su arbitraria e ilusoria normalidad. ${ }^{27}$

El cardenal, "intelecto de cuarta y ... sensibilidad de tercera en una dignidad de primerísima categoría", según Rodríguez Juliá, "secuestra la palabra con ... paternalismo exasperante de cura pueblerino", sólo capaz de "tropezar"(El entierro, 45-46) a veces con la verdad, como cuando acierta a reconocer la generosidad artística que hace merecer un homenaje popular a Cortijo. Es un personaje que sortea las exequias como problema de imagen pública del cargo, para evitar el posible ridículo de su boato en una actividad bastante desplazada de las esferas culturales donde funciona.

Por otro lado, el anhelo de Rodríguez Juliá de narrar el episodio de la segunda época de la plena como hito continuador de una tradición alternativa frente a las distopías de las elites coloniales que tanto escepticismo provocan en él, no obstaculiza su juicio crítico. La reverencia por la "obra monumental", representativa de "un salto arriesgado de dos décadas" (Entierro 37), creada por Cortijo y sus seguidores, es lo que conduce al escritor al entierro. Puntualiza con cuidado, además, el modo en que Cortijo revolucionó el panorama musical con un estilo dinámico de combo, que rompióla formalidad de las grandes orquestas, unificó el baile y la música y transformó el ingrediente mulato y negro de la música popular en verdadera presencia social. Llega a afirmar que la plena de Cortijo profundiza en mayor medida que el jazz norteamericano, el sentido comunitario de la música popular (Entierro 31-32). Pero también señala que esa misma plena, montada en la marea del populismo desarrollista de posguerra:

abandona el contorno proletario y se acerca a los límites imprecisos de un lenguaje en clave, para iniciados, jerga del exclusivismo lumpen del arrabal y el caserío. Toda la música de Cortijo es así, rica en connotaciones malevas y pobre en denotaciones realistas (Entierro 71).

Su letra deviene "puro motivo para el soneo, relato sin otro referente que su propia gracia" (Entierro 71), y pierde el valor de crónica histórica de las plenas

\footnotetext{
${ }^{27}$ Maertens, Le Jeu 73.
} 
de la época de Canario, lo cual significa para Rodríguez Juliá que "se ha resquebrajado el mundo proletario" (Entierro 71). La caída en la adicción a drogas, las consiguientes secuelas de cárcel y enfermedad, y otros desarreglos que afectan a los representantes de esa música acentúan el tono de tragedia que el desenlace de la muerte de Cortijo hace cobrar al episodio de la segunda época de la plena.

Hay quien percibe que a los períodos de reflujo organizativo de la clase obrera en nuestro país, ha correspondido una disolución de los elementos de cultura alternativa que sus luchas han forjado. ${ }^{28}$ Se trata, por supuesto, de formas culturales muy ligadas al proceso político y gremial. En el campo artístico-creativo cabría esperar desfases y mediaciones mayores. El texto de Rodríguez Juliá no examina un proceso histórico que explique ese resquebrajamiento del mundo proletario en la letra de la plena, pero sus repetidas alusiones al desarrollismo muñocista que le es contemporáneo, delinean sin embargo una correspondencia. ${ }^{29}$

El narrador somete a igual visión crítica la conducta de las masas en el entierro cuando percibe la confusión de duelo y novelería, de ternura desaforada $\mathrm{y}$ "puro vacilón lumpen" ( $\mathrm{El}$ entierro, 85) en diversos gestos descritos por la crónica. La multitud aplaude con vítores una despedida de duelo, lanza coronas de flores por el aire o la tierra del camposanto, no conviene en el orden o sentido de sus tributos improvisados:

¿Dónde zozobró esa memoria de las cosas y los gestos que es la tradición? ¿Por dónde anda un pueblo que apenas puede conciliar sus actos con sus sentimientos, o aquellos con el rito? ... El rito anda moribundo, hay tantas intenciones fantasmales y tantos gestos insepultos. Posiblemente en ello resida eso que tan solemnemente llamamos crisis historica. ${ }^{30}$

Ni siquiera al concluir el acto pueden confirmarse señales de certidumbre. Las jovencitas que improvisan pasos de plena sobre la tapia aún húmeda de la tumba, configuran (en "gesto heroico") una suerte de tributo a Cortijo, pero, seguidamente, gritan improperios a uno de sus grandes continuadores latinoamericanos en la presente fase de lasalsa (integradora de numerosos ritmos

${ }^{28}$ Ángel G. Quintero Rivera, "Clases sociales e identidad nacional; notas sobre el desarrollo nacional puertorriqueño", en Quintero Rivera et al., Puerto Rico: identidad nacional y clases sociales (Coloquio de Princeton), (Río Piedras: Huracán, 1981) 43-44.

${ }^{29}$ Tocaría a nuestra crítica cultural ubicar la plena y otros episodios de ese tipo dentro de procesos especificos del desarrollismo populista, tales como el crecimiento de la poblacion queva perdiendo participación en las experiencias de la clase obrera, olas discontinuidades (borradura de tradiciones de lucha, control ideológico, interferencia cultural colonial, desplazamiento de ámbitos o expectativas sociales, etc.) que afectan al propio movimiento obrero a lo largo de esa fase.

${ }^{30}$ Rodriguez Juliá, El entierro 95. Subrayados del autor. 
afroantillanos), Rubén Blades, cuando éste reprende su risería y bachata. "La tradición estalla en mil pedazos, ¿cómo conciliar tanto extravío con tanta ternura?" (El entierro 96), debe concluir, sin pausa, el narrador.

Edgardo Rodríguez Juliá no mistifica la multitud, a pesar de narrarla como enigma. Quizá parcializa su descripción inventariando demasiado una galería de tipos callejeros y gestos extremos dentro del conjunto de la procesión, seleccionando, sobre otras, las manifestaciones de ese sector clasificable como lumpen-proletariado dentro de la formación social puertorriqueña. ¿Pero puede ser producto de alguna selección prejuiciada la preponderancia del llamado lumpen-proletariado dentro de cualquier visión de una multitud callejera de puertorriqueños? ¿No sería más prejuiciada su exclusión? ¿No constituyen sus manifestaciones un espectro que recae sobre el conjunto de las capas sociales? Desde el principio el texto relativiza la etiqueta "lumpen" que a veces exime la conciencia de muchos críticos sociales puertorriqueños de un análisis de la contradictoriedad socio-cultural de las masas trabajadoras del país. Enfrenta, sin pregonar fáciles epígonos (¿héroes proletarios-puros?) de una cultura de liberación, la explosiva imagen proyectada por la paradoja socioeconómica de esta última colonia imperial, tan desarrollada como antidesarrollada, donde la alta tasa de producción industrial y el exhuberante intercambio de mercancías acompañan la generalización del desempleo, la marginación social y la caída precipitada de los ingresos reales, provocando que más de la mitad de las familias del país dependa de prestaciones públicas directas para satisfacer necesidades básicas ${ }^{31}$ La crónica practica una noción de "lumpenidad" que no designaría tanto un estrato social específico, como una generalización de elementos alienantes dentro de las diversas prácticas culturales puertorriqueñas. Estos elementos inciden de diversa manera (reforzándolas, dispersándolas, etc.) en las acciones creativas y liberadoras que la resistencia contra la ilogicidad opresiva y explotadora del sistema genera. Al captar ese drama dialéctico este relato provee una visión desmistificadora de la tradición popular y contribuye a calibrar sus posibilidades reales.

El episodio de la segunda época de la plena no se prolonga con fácil continuidad dentro de la matriz social que lo sobrevive y ahora celebra el entierro de su máximoexponente. "La tradición estallaen mil pedazos" —advierte la crónica ante quien intente leer (o narrar) el desarrollo de una forma artística popular como si formara parte de un proceso lineal y unitario. Dicha perspectiva coincide con la de quien afirma, como Terence Eagleton, que la tradición popular, en el sentido benjaminiano, no consiste en una sucesión de episodios consecutivos que marchan por debajo de La Historia (con mayúscula) de los explotadores, invirtiéndola consistentemente:

\footnotetext{
${ }^{31}$ Frank Bonilla y Ricardo Campos, "Imperialist Iniciatives and the Puerto Rican Worker: From Foraker to Reagan", en Contemporary Marxism 3 (1983) 12 y ss.
} 
La tradición [popular] no es otra cosa que una serie de espasmos o crisis dentro de la historia de clases misma, un conjunto de articulaciones de esa historia, no las letras dispersas de alguna palabra invisible. ${ }^{32}$

Podríamos añadir: no de alguna palabra inversa por ser leída ante el espejo de los explotadores. Nuestro narrador no puede leer esa palabra en la multitud, sino las interrogaciones que sus movimientos reflejan. El correlato alegórico queda por hacer, más allá de los textos. La unidad de las creaciones monumentales que iluminan la tradición popular no radica en la palabra del pasado, sino en un futuro aún por pronunciar. Coexisten gestos elaborados, como el de Maelo, gestos incompletos, como los de las chicas, y otros, todavía vacíos, pero quedan por hacerse valer como experiencia de oposición, en instancias específicas de contienda política. Es ciertoque el proyecto puertorriqueño de una nueva cultura y sociedad halla sus raíces en los grandes hechos y obras del pasado, realizados sobre todo por las manos de aquellos que lucharon y trabajaron, como anuncia el himno "Oubuao Moin" de Corretjer. Mas, por ello mismo, el árbol de la tradición popular debe hallar su floración liberadora en el futuro. Carlos Marx hubo de hablar también del siglo veinte, condenando no el aprendizaje del pasado, sino su mistificación, al escribir:

La revolución social del siglo XIX no puede sacar su poesía del pasado, sino solamente del porvenir. No puede comenzar su propia tarea antes de despojarse de toda veneracion supersticiosa por el pasado. Las anteriores revoluciones necesitaban remontarse a los recuerdos de la historia universal para aturdirse acerca de su propio contenido. La revolución del siglo XIX debe dejar que los muertos entierren a los muertos, para cobrar conciencia de su propio contenido. ${ }^{39}$

Según la crónica, Luis Ambrosio de Jesús proclama, en la despedida de duelo de Cortijo: "Vivirás, Rafael, tú vivirás" (Entierro 91). Cabe añadir que corresponderá a los vivos resucitar a los vivos.

\footnotetext{
${ }^{32}$ Terence Eagleton, Walter Benjamin or Toward a Revolutionary Criticism (Londres: NLB, 1981) 48.

${ }^{33}$ Carlos Marx, El dieciocho de Brumario de Luis Bonaparte (Moscú: Editorial Progreso, s.f.) 12.
} 
